\title{
11B NMR Spectroscopy of Lead Borate Glasses: Additive Effect of Cerium Oxide
}

\author{
Gomaa El-Damrawi1', Fawzia Gharghar1, Rawia Ramadan², Mohamed Aboelez ${ }^{3}$ \\ ${ }^{1}$ Glass Research Group, Physics Department, Faculty of Science, Mansoura University, Mansoura, Egypt \\ ${ }^{2}$ Microwave and Dielectric Department, Physics Division, National Research Centre, Giza, Egypt \\ ${ }^{3}$ Faculty of Engineering, Monofya University, Sheben Elkom, Egypt \\ Email: gomaaeldamrawi@gmail.com
}

How to cite this paper: El-Damrawi, G., Gharghar, F., Ramadan, R. and Aboelez, M. (2016) ${ }^{11}$ B NMR Spectroscopy of Lead Borate Glasses: Additive Effect of Cerium Oxide. New Journal of Glass and Ceramics, 6, 57-63.

http://dx.doi.org/10.4236/njgc.2016.64007

Received: August 21, 2016

Accepted: October 8, 2016

Published: October 11, 2016

Copyright $\odot 2016$ by authors and Scientific Research Publishing Inc. This work is licensed under the Creative Commons Attribution International License (CC BY 4.0).

http://creativecommons.org/licenses/by/4.0/

\begin{abstract}
Glasses and glass ceramics in the system $\mathrm{xCeO}_{2} \cdot(50-\mathrm{x}) \mathrm{PbO} \cdot 50 \mathrm{~B}_{2} \mathrm{O}_{3}(0 \leq \mathrm{x} \leq 50)$ have been studied, for the first time, by NMR and FTIR techniques. Effect of $\mathrm{CeO}_{2}$ substitution with $\mathrm{PbO}$ on NMR parameters has been discussed in terms of changing both boron and cerium coordination. The quantitative fraction of four coordinated boron $\left(\mathrm{N}_{4}\right)$ has been simply determined from ${ }^{11} \mathrm{~B}$ NMR spectroscopy. On the other hand, the fraction of total tetrahedral structural units $\mathrm{B}_{4}\left(\mathrm{BO}_{4}+\mathrm{PbO}_{4}+\mathrm{CeO}_{4}\right)$ is obtained from FTIR spectral analysis. It is not possible to get the fraction of cerium oxide directly from the applied spectroscopic tools. Therefore, a simple approach is applied, for the first time, to determine $\mathrm{CeO}_{4}$ fraction by using the different criteria of both ${ }^{11} \mathrm{~B}$ NMR and FTIR spectroscopy. The fraction of $\mathrm{B}_{4}$ species is equal to $\mathrm{N}_{4}$, within the experimental error, of the same glasses in the composition region of up to $10 \mathrm{~mol}_{0} \mathrm{CeO}_{2}$. On the other hand, there is a clear difference between both $\mathrm{N}_{4}$ and $\mathrm{B}_{4}$ values in glasses of higher $\mathrm{CeO}_{2}$ content $(>10 \mathrm{~mol} \%)$. The related difference showed a linear increasing trend with increasing the content of $\mathrm{CeO}_{2}$ in the glass. This was discussed on the bases of structural role of $\mathrm{CeO}_{2}$ which acts as a glass former in the region $>10 \mathrm{~mol} \%$, while, at lower concentration, it consumed as a glass modifier.
\end{abstract}

\section{Keywords}

New Approach, Cerium Oxide, Boron Fraction

\section{Introduction}

Borate glasses containing $\mathrm{CeO}_{2}$ and $\mathrm{PbO}$ are used in wide field of applications. This may be due to their distinction features including wide glass forming region and low thermal expansion [1]-[4]. Several investigations have been reported on the structure of 
lead containing glasses [2]-[6]. It was concluded that glass and glass ceramics containing high concentration from $\mathrm{PbO}$ are of great importance from the viewpoint of glass formation. This may because $\mathrm{PbO}$ in such a case inters the network of the glass as $\mathrm{s}$ former.

In the low $\mathrm{PbO}$ content (up to $50 \mathrm{~mol} \%$ ), majority of $\mathrm{PbO}$ act as a network modifier. The reverse behavior is found in binary $\mathrm{CeO}_{2}-\mathrm{B}_{2} \mathrm{O}_{3}$ glasses, since cerium oxide acts as a glass former [3] [4]. Each atom of $\mathrm{PbO}$ added is used to convert two $\mathrm{BO}_{3}$ species into two $\mathrm{BO}_{4}$ units. The fraction of $\mathrm{BO}_{4}$ groups increases with increasing $\mathrm{PbO}$ contents reaching maximum value $\sim 0.50-0.53$ [7]-[10] at equal amount of $\mathrm{PbO}$ and $\mathrm{B}_{2} \mathrm{O}_{3}$ oxides. Further increase of $\mathrm{PbO}$ content decreases the number of $\mathrm{BO}_{4}$ units by forming nonbridging oxygen atoms in glass network. In such situation $\mathrm{Pb}$ ions are mainly surrounded by two $\mathrm{BO}_{4}$ tetrahedral units and in part by $\mathrm{BO}_{3}$ units with NBOs [11]. But major portion of $\mathrm{CeO}_{2}$ inters the network of the glass as a modifier at extremely high contents (40-60 mol \%) [3].

In this paper, the structure of $\mathrm{CeO}_{2}-\mathrm{PbO}-\mathrm{B}_{2} \mathrm{O}_{3}$ glasses is investigated by means of FTIR absorbance and NMR techniques with an aim to determine the structure role of cerium in ternary cerium lead borate glasses. In this regard, there is a remarkable lack and shortage information about the role of ceria in glass ceramics.

\section{Experimental Details}

\subsection{Glasses Preparation}

The glass samples were prepared by mixing and fusing the desired amount of $\mathrm{CeO}_{2}$, $\mathrm{PbO}$, and $\mathrm{H}_{3} \mathrm{BO}_{3}$ compounds in alumina crucibles. The melting process was carried out at different temperatures depending on the glass compositions. The glasses were prepared with a wide variety of the cerium oxide concentration which is varied from 2.5 to $50 \% \mathrm{CeO}_{2}$. The melt was swirled frequently and then poured on stainless steel plate and pressed by another plate to get disc like shape.

\section{2. ${ }^{11 B}$ NMR Measurements}

All samples were measured with JEOL GSX-500 high-resolution solid-state MAS NMR spectrometer in a magnetic field of $11.4 \mathrm{~T}$. ${ }^{11} \mathrm{~B}$ MAS NMR spectra were recorded at a frequency of $160.4 \mathrm{MHz}$ and spinning rate of $15 \mathrm{KHz}$. The glass samples were measured with a single pulse length of $0.5-1.0 \mathrm{~ms}$ and a pulse delay of $2.5 \mathrm{~s}$, and an accumulation of 200 - 300 scans is obtained.

\section{Results and Discussion}

\subsection{Binary Borate Glasses}

NMR spectra of both $50 \mathrm{CeO}_{2}-50 \mathrm{~B}_{2} \mathrm{O}_{3}$ and $50 \mathrm{PbO}-50 \mathrm{~B}_{2} \mathrm{O}_{3}$ binary glasses are presented in Figure 1. It is clear from this figure that there is a great difference between the features of the two spectra. In case of $\mathrm{PbO}-\mathrm{B}_{2} \mathrm{O}_{3}$ glass (free from cerium), well resolved rsonance peaks characterizing $\mathrm{BO}_{3}$ (both in ring and nonring) and $\mathrm{BO}_{4}$ groups are 


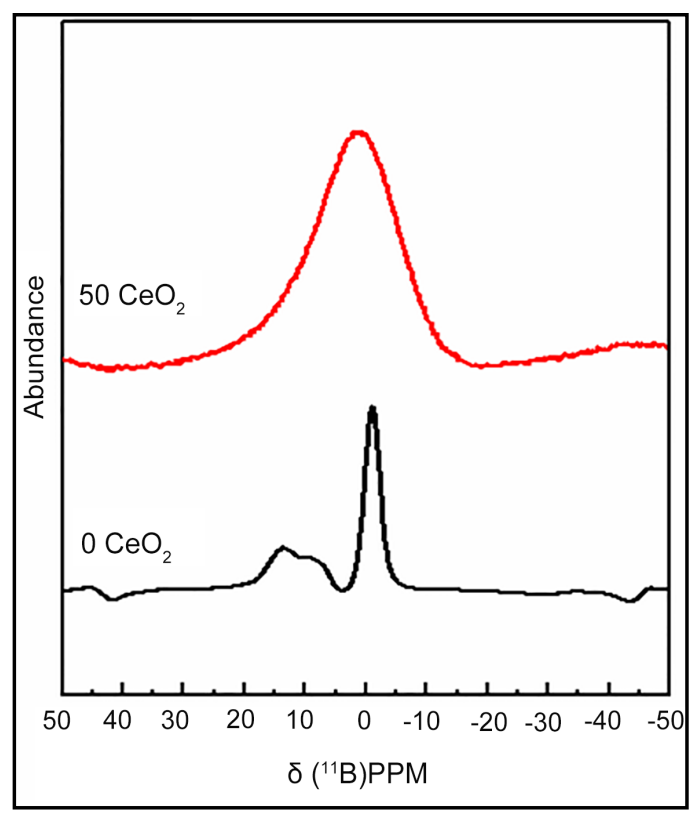

Figure 1. ${ }^{11} \mathrm{~B}$ NMR spectra of cerium free (at the bottom) and of glass contains $50 \mathrm{~mol} \% \mathrm{CeO}_{2}$.

clearly distinguished. The fraction of boron tetrahedral units is $\sim 0.53$ which means that $53 \%$ from the total boron is found in its tetrahedral coordination with oxygen atoms. This suggests that the majority of $\mathrm{PbO}$ is consumed as a glass modifier. It converts two $\mathrm{BO}_{3}$ units to two $\mathrm{BO}_{4}$ groups. On the other hand, broader and anti-symmetric NMR band of $\mathrm{CeO}_{2}-\mathrm{B}_{2} \mathrm{O}_{3}$ glass are clearly evidenced by the effect of $\mathrm{CeO}_{2}$. It can be seen from the ${ }^{11} \mathrm{~B}$ spectrum of the glass that the bands characterizing $\mathrm{BO}_{3}$ is diluted by $\mathrm{CeO}_{2}$. As a result, a wide spectrum containing overlapped peaks characterizing $\mathrm{BO}_{3}$ and $\mathrm{BO}_{4}$ is obtained, see Figure 1. The fraction of tetrahedral boron is much lower than that of lead borate glass, since the determined value of $\mathrm{B}_{4}=0.34$.

Similar observation can be also found in FTIR absorbance spectra of the two glasses, see Figure 2. It can be seen from the spectrum of cerium free glass that individual resonances representing $\mathrm{BO}_{3}$ and $\mathrm{BO}_{4}$ are markedly distinguished. Higher $\mathrm{CeO}_{2}$ concentration (50 mol\%) leads to appearing of broader and anti-symmetric FTIR resonance band. This wide band is assigned to mixed $\mathrm{Ce}_{4}-\mathrm{O}, \mathrm{B}_{4}-\mathrm{O}$ and $\mathrm{B}_{3}-\mathrm{O}$ stretching vibration mode.

\subsection{Ternary Cerium Lead Borate Glasses}

There are two main spectral regions which characterize the NMR resonance modes of the ternary glass network. The first is dominant in glass of $0 \leq \mathrm{CeO}_{2} \leq 10 \mathrm{~mol} \%$, since both resonance spectra characterizing separated $\mathrm{BO}_{3}$ and $\mathrm{BO}_{4}$ groups are clearly appeared [12]-[15] (Figure 3). The wide spectral band of chemical shift exists between 11 $20 \mathrm{ppm}$ is attributed to $\mathrm{BO}_{3}$ (both in ring and nonring) groups [12] [13]. The second appears at $0 \mathrm{ppm}$ which is due to tetrahedral $\mathrm{BO}_{4}$ units. An extra increase in $\mathrm{CeO}_{2}$ at expense of $\mathrm{PbO}$ concentration will result in overlapping resonance spectra characteriz- 
ing both $\mathrm{BO}_{3}$ and $\mathrm{BO}_{4}$ groups. This may reflect change in structure role of cerium oxide in this composition region, since it acts as a glass former [1] [13] [16] [17]. As a direct result, tetrahedral $\mathrm{CeO}_{4}$ species are suggested to be formed upon a frequent replacement of $\mathrm{CeO}_{2}$ with $\mathrm{PbO}$. Increasing concentration of $\mathrm{CeO}_{4}$ groups is accompanied with a decrease in the fraction of $\mathrm{BO}_{4}$ units. This is because part of modifier oxide is consumed to modify $\mathrm{CeO}_{2}$ network. The same feature is reported in detail in our previous work [18] on the same glasses investigated by FTIR spectroscopy.

Figure 4 represents the changes of $\mathrm{B}_{4}$ and $\mathrm{N}_{4}$ fractions with $\mathrm{CeO}_{2}$ concentration. The $\mathrm{B}_{4}$ can be showed to change with different rates upon addition of $\mathrm{CeO}_{2}$ concentration.

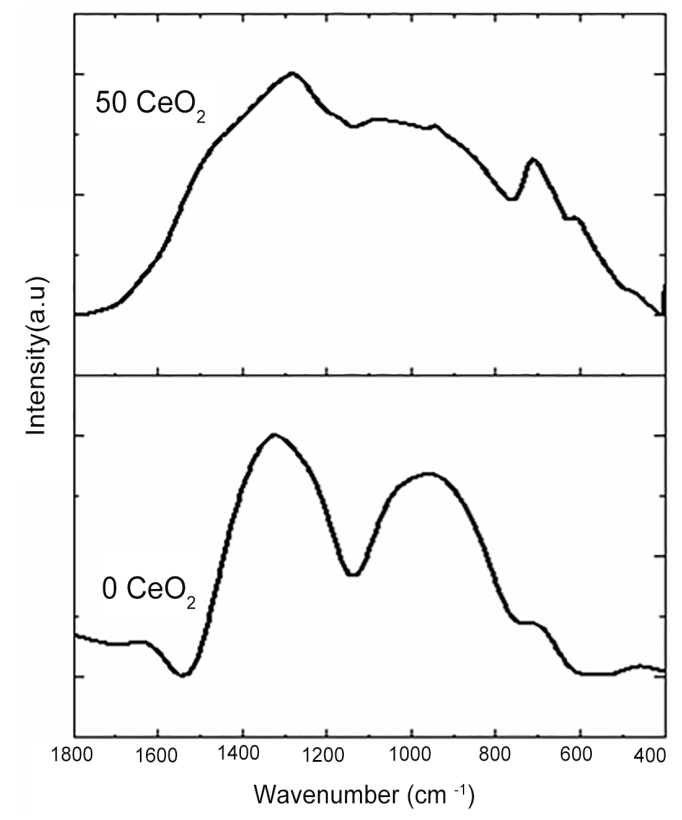

Figure 2. FTIR absorbance spectra of cerium free (at the bottom) and of glass contains $50 \mathrm{~mol} \% \mathrm{CeO}_{2}$.
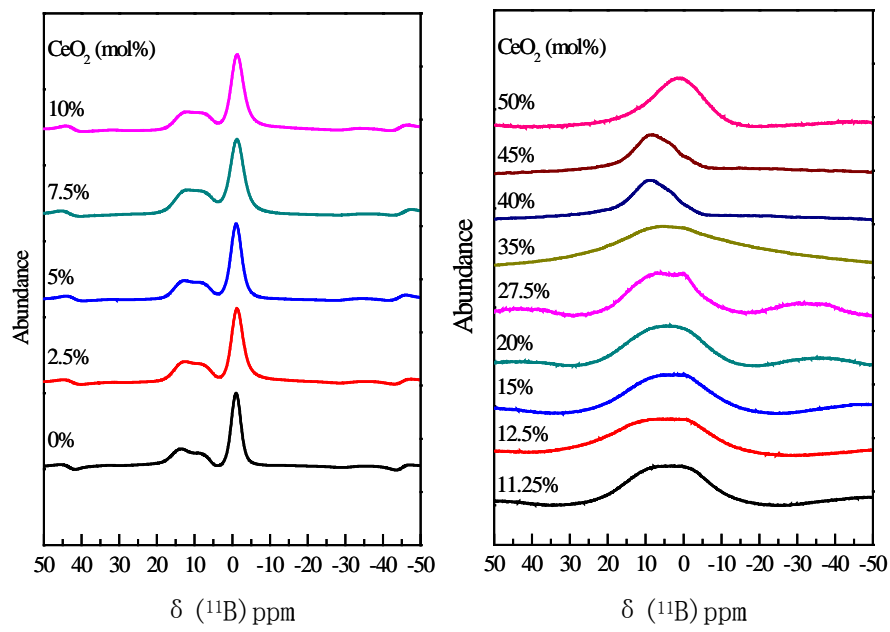

Figure 3. ${ }^{11} \mathrm{~B}$ spectra for $\mathrm{CeO}_{2}-\mathrm{PbO}-\mathrm{B}_{2} \mathrm{O}_{3}$ glasses at different $\mathrm{CeO}_{2}$ concentrations. 
First, both $\mathrm{B}_{4}$ and $\mathrm{N} 4$ value in both cases changes slightly around fixed value with introducing $\mathrm{CeO}_{2}$ up to $\sim 10 \mathrm{~mol} \%$. This little difference between the two fraction $\left(\mathrm{B}_{4}\right.$ and $\mathrm{N}_{4}$ ) may be considered due to the same role of both lead and cerium as glass modifier, since substitution of $\mathrm{PbO}$ by $\mathrm{CeO}_{2}$ hasn't remarkable effect on both values. Further substitution of $\mathrm{PbO}$ by $\mathrm{CeO}_{2}$ (in the region $>10 \mathrm{~mol} \%$ ) will result in decreasing in both $\mathrm{B}_{4}$ and $\mathrm{N}_{4}$ with different rates. Moreover, the differences between them increase with increasing $\mathrm{CeO}_{2}$ contents. Increasing differences between $\mathrm{B}_{4}$ and $\mathrm{N}_{4}$ may lead to conclusion that the ability of $\mathrm{CeO}_{2}$ to act as a glass former is increased with its content. Thus the formation of $\mathrm{CeO}_{4}$ groups as the most dominate species in this region is considered as the main reason of reduction in the tetrahedral $\left(\mathrm{BO}_{4}\right)$ groups in the glass network. As a direct effect, $\mathrm{B}_{4}$ is abruptly decreased upon more addition of $\mathrm{CeO}_{2}$ (see Figure 4). The difference between $\mathrm{B}_{4}$ and $\mathrm{N}_{4}$ for each composition gives a quantitative concentration of $\mathrm{CeO}_{4}$ fraction as a glass former. Figure 5 presents the change of $\mathrm{CeO}_{4}$.

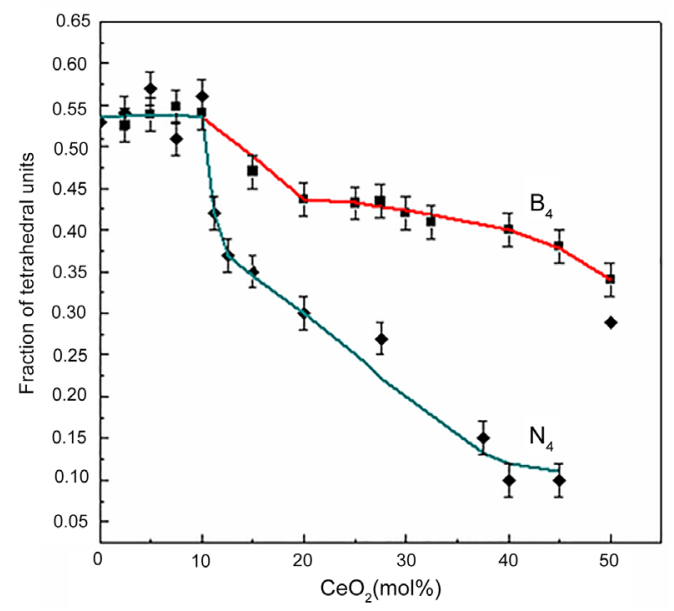

Figure 4. Changes of $\mathrm{B}_{4}$ and $\mathrm{N}_{4}$ fraction as function of $\mathrm{CeO}_{2}$ concentration.

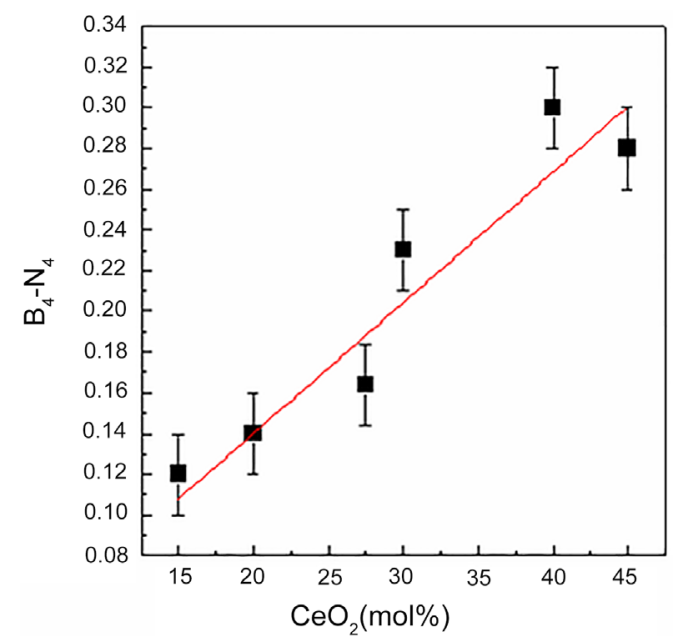

Figure 5. Changes of $\mathrm{Ce}_{4}$ fraction as function of $\mathrm{CeO}_{2}$ concentration. 
fraction with $\mathrm{CeO}_{2}$ contents. $\mathrm{Ce}_{4}$ is observed to increase linearly with increasing $\mathrm{CeO}_{2}$ concentration. The linear correlation between $\mathrm{Ce}_{4}$ and $\mathrm{CeO}_{2}$ concentration leads to confirm that most of all $\mathrm{CeO}_{2}$ inters the glass network as a strong glass former.

Based upon the above considerations, we suggest that $\mathrm{Ce}$ (in high $\mathrm{CeO}_{2}$ ) glasses has strong ability to form its own structural units and preferentially bridge to $\mathrm{BO}_{3}$ rather than increasing number of tetrahedral $\mathrm{BO}_{4}$ groups. For this reason both $\mathrm{B}_{4}$ and $\mathrm{N}_{4}$ values are continuously decreased with increasing $\mathrm{CeO}_{2}$ contents.

\section{Conclusion}

Glasses in system of $\mathrm{xCeO}_{2} \cdot(50-\mathrm{x}) \mathrm{PbO} \cdot 50 \mathrm{~B}_{2} \mathrm{O}_{3}$ with $0 \leq \mathrm{x} \leq 50 \mathrm{~mol} \%$ have been investigated, for the first time, by ${ }^{11} \mathrm{~B}$ NMR structural technique. It is evidenced that cerium and lead ions play a dual role in the studied system. In low $\mathrm{CeO}_{2}$ content, $\leq 10 \mathrm{~mol}$, $\mathrm{CeO}_{2}$ plays a modifier role. The structure role of $\mathrm{CeO}_{2}$ is changed from modifier to a glass former at higher content. The fraction of the tetrahedral cerium $\left(\mathrm{Ce}_{4}\right)$ as a former species is determined from a suggested approach which is based on correlation between structural feature obtained from both NMR and FTIR analysis. Accordingly, $\mathrm{Ce}_{4}$ fraction is determined from the differences between values of $\mathrm{B}_{4}$ and $\mathrm{N}_{4}$.

\section{References}

[1] Gautam, C., Yadav, A.K. and Singh, A.K. (2012) A Review on Infrared Spectroscopy of Borate Glasses with Effects of Different Additives. ISRN Ceramics, 2012, Article ID: 428497. http://dx.doi.org/10.5402/2012/428497

[2] Wadate, Y., Hattori, T., Nishiyama, S., Fukushima, K., Igawa, N. and Noda, K. (1996) Short-Range Structural Analysis of an Oxide Glass Composed of Light and Heavy Elements: 3B2O3-2PbO Glass by X-Ray Diffraction. Journal of Material Science Letters, 15, 776-780. http://dx.doi.org/10.1007/BF00274601

[3] El-Damrawi, G. and El-Egili, K. (2001) Characterization of Novel $\mathrm{CeO}_{2}-\mathrm{B}_{2} \mathrm{O}_{3}$ Glasses, Structure and Properties. Physica B, 299, 180-186. http://dx.doi.org/10.1016/S0921-4526(00)00593-7

[4] Singh, G.P., Kaur, P., Kaur, S.P. and Singh, D.P. (2012) Conversion of Covalent to Ionic Character of $\mathrm{V}_{2} \mathrm{O}_{5}-\mathrm{CeO}_{2}-\mathrm{PbO}-\mathrm{B}_{2} \mathrm{O}_{3}$ Glasses for Solid State Ionic Devices. Physica B, 407, 4269-4273. http://dx.doi.org/10.1016/j.physb.2012.07.015

[5] Terashima, K., Hashimoto, T. and Yoko, T. (1997) Structure and Nonlinear Optical Properties of $\mathrm{PbO}-\mathrm{Bi}_{2} \mathrm{O}_{3}-\mathrm{B}_{2} \mathrm{O}_{3}$ Glasses. Physics and Chemistry of Glasses, 38, 211-217.

[6] Mao, D. and Bray, P.J. (1992) ${ }^{11} \mathrm{~B}$ NQR and NMR Studies of Lead Borates. Journal of Non-Crystalline Solids, 144, 217-223. http://dx.doi.org/10.1016/S0022-3093(05)80403-X

[7] Doweidar, H., El-Damrawi, G., Mansour, E. and Fetouh, R.E. (2012) Structural Role of $\mathrm{MgO}$ and $\mathrm{PbO}$ in $\mathrm{MgO}-\mathrm{PbO}-\mathrm{B}_{2} \mathrm{O}_{3}$ Glasses as Revealed by FTIR; a New Approach. Journal of Non-Crystalline Solids, 358, 941-946. http://dx.doi.org/10.1016/j.jnoncrysol.2012.01.004

[8] Doweidar, H., Gohar, I.A., Megahed, A.A. and El-Damrawi, G. (1991) Structure-Transport Relationships in Lead Borate Glasses Containing $\mathrm{V}_{2} \mathrm{O}_{5}$. Solid State Ionics, 46, 275-281. http://dx.doi.org/10.1016/0167-2738(91)90226-2

[9] Takaishi, T., Jin, J., Uchino, T. and Yoko, T. (2000) Structural Study of PbO- $\mathrm{B}_{2} \mathrm{O}_{3}$ Glasses by X-Ray Diffraction and ${ }^{11} \mathrm{~B}$ MAS NMR Techniques. Journal of the American Ceramic Society, 83, 2543-2548. http://dx.doi.org/10.1111/j.1151-2916.2000.tb01588.x 
[10] Doweidar, H., El-Igili, K. and Abd El-Maksoud, S. (2000) Correlations between Properties and Structure in CuO-PbO- $\mathrm{B}_{2} \mathrm{O}_{3}$ Glasses. Journal of Physics D: Applied Physics, 33, $2532-$ 2537.

[11] Saini, A., Khanna, A., Michaelis, V.K., Kroeker, S., Gonzalez, F. and Hernandez, D. (2009) Structure-Property Correlations in Lead Borate and Borosilicate Glasses Dopped with Aluminum Oxide. Journal of Non-Crystalline Solids, 355, 2323-2332.

http://dx.doi.org/10.1016/j.jnoncrysol.2009.08.006

[12] Kroeker, S. and. Stebbins, J.F. (2001) Three-Coordinated Boron-11 Chemical Shifts in Borates. Inorganic Chemistry, 40, 6239-6246. http://dx.doi.org/10.1021/ic010305u

[13] Aguiar, P.M. and Kroeker, S. (2005) Medium-Range Order in Cesium Borate Glasses. Solid State Nuclear Magnetic Resonance, 27, 10-15. http://dx.doi.org/10.1016/j.ssnmr.2004.08.009

[14] Singh, G.P., Kaur, P., Kaur, S.P., Kaur, R. and Singh, D.P. (2013) Conversion of $\mathrm{Ce}^{+3}$ to $\mathrm{Ce}^{+4}$ Ions after Gamma Ray Irradiation on $\mathrm{CeO}_{2}-\mathrm{PbO}-\mathrm{B}_{2} \mathrm{O}_{3}$ Glasses. Physica B, 408, 115-118. http://dx.doi.org/10.1016/j.physb.2012.09.005

[15] Culea, E., Pop, L. and Bosca, M. (2010) Structural and Physical Characteristics of $\mathrm{CeO}_{2}$ $\mathrm{GeO}_{2}-\mathrm{PbO}$ Glasses and Glass Ceramics. Journal of Alloys and Compounds, 505, 754-757. http://dx.doi.org/10.1016/j.jallcom.2010.06.135

[16] Marzouk, S.Y. and Ezz-Eldin, F.M. (2008) Optical study of $\mathrm{Ce}^{3+}$ Ion in Gamma-Irradiated Binary Barium-Borate Glasses. Physica B, 403, 3307-3315. http://dx.doi.org/10.1016/j.physb.2008.04.041

[17] Kutub, A.A., Elmanharawy, M.S. and Shawoosh, A.S. (1996) Optical Proprties of Irradiated Sodium Diaborate Glasses Containing Copper and Cerium. Physica Status Solidi $(A), 155$, 239-248. http://dx.doi.org/10.1002/pssa.2211550124

[18] El-Damrawi, G., Gharghar, F. and Ramadan, R. (2016) Structural Studies on New $\mathrm{CeO}_{2} \cdot(50-\mathrm{x}) \mathrm{PbO} \cdot 50 \mathrm{~B}_{2} \mathrm{O}_{3}$ Glasses and Glass Ceramics. Journal of Non Crystalline Solids, 452, 291-296.

Submit or recommend next manuscript to SCIRP and we will provide best service for you:

Accepting pre-submission inquiries through Email, Facebook, LinkedIn, Twitter, etc. A wide selection of journals (inclusive of 9 subjects, more than 200 journals)

Providing 24-hour high-quality service

User-friendly online submission system

Fair and swift peer-review system

Efficient typesetting and proofreading procedure

Display of the result of downloads and visits, as well as the number of cited articles Maximum dissemination of your research work

Submit your manuscript at: http://papersubmission.scirp.org/

Or contact njgc@scirp.org 